\title{
COL3A1 wt Allele
}

National Cancer Institute

\section{Source}

National Cancer Institute. COL3A1 wt Allele. NCI Thesaurus. Code C143053.

Human COL3A1 wild-type allele is located in the vicinity of 2 q32.2 and is approximately 38 $\mathrm{kb}$ in length. This allele, which encodes collagen alpha-1(III) chain protein, is involved in collagen formation. Mutations in this gene are associated with Ehlers-Danlos syndrome type IV, aortic and arterial aneurysms and lipoblastoma. 